\title{
Development and culture: in search of a lost agenda
}

Desenvolvimento e cultura: em busca de uma agenda perdida

Fabricio J. Missio (1)

Humberto Martins (2)

(1) Universidade Federal de Minas Gerais

(2) Universidade Federal de Uberlândia

\begin{abstract}
The debate about culture is a key issue for economic theory and for proposing new developmental policies. Despite this, some recent approaches have hardly incorporated or explored culture. Thus, identifying this gap in the literature, we explore the relationship between culture and development. Firstly, we analyse this relationship in new mainstream approaches, identifying their limitations. Then, we discuss the developmentalist approach, underlining the structural and unbalanced conception. Sequentially, and somewhat inspired by the latter, we examine new approaches that share the structural perspective, such as the post-Keynesian and institutionalist approaches. We conclude that the developmentalist approach has contributed to amplifying the integration of culture and development and that these new "non-neoclassical" conceptions reveal an interesting potential for incorporating the cultural dimension of development.
\end{abstract}

\section{Keywords}

development, culture, developmentalist approach; structuralism.

JEL Codes B52, O11, Z10.

\section{Resumo}

O debate sobre cultura é uma questão fundamental para a proposição de novas politicas de desenvolvimento. Apesar disso, algumas abordagens recentes têm incorporado ou explorado esta questão de forma limitada. Assim, a partir da identificação dessa lacuna na literatura, este artigo busca explorar a relação entre cultura e desenvolvimento. Em primeiro lugar, analisamos essa relação nas abordagens recentes no campo do 'mainstream', identificando suas limitações. Em seguida discutimos a abordagem desenvolvimentista, destacando sua concepção estruturalista e desigual. Inspirados por essa abordagem, sequencialmente examinamos duas concepções teóricas recentes que compartilham uma perspectiva estrutural, a saber a pós-Keynesiana e a institucionalista. Concluimos que a abordagem desenvolvimentista contribuiu para ampliar a integração da cultura e do desenvolvimento e que essas novas abordagens "não neoclássicas" mostram um potencial interessante para incorporar a dimensão cultural do desenvolvimento.

\section{Palavras-chave}

desenvolvimento, cultura, abordagem desenvolvimentista, estruturalismo.

Códigos JEL B52, O11, Z10. 


\section{Introduction}

"Our worst fears, like our greatest hopes, are not outside our powers, and we can come in the end to triumph over the former and to achieve the latter."

Marcel Proust, In Search of Lost Time

The cultural dimension of the developmental process constitutes a key question for the current debate on development and for the proposal of developmental policies. It is receiving increasing attention in contemporary discussion. Of course, how culture can affect development depends on the perspective assumed. For example, based on a more conservative approach, some studies seek to show the role of culture and institutions in explaining the success (or failure) of specific countries or regions (Guiso et al., 2006; Landes, 1998). On the other hand, progressive institutionalists and post-Keynesian authors deal with the theme in a broader (and, in our view, more interesting) perspective, allowing us to incorporate new viewpoints on the role of culture in development (see Hodgson, 2006; Jackson, 1993).

From the mid-20 th century, the group of authors usually classified as developmentalists fruitfully analysed the relationship between culture and development. They have explored the role of culture and institutions in their investigation of the developmental process. In their analysis, culture is incorporated in a broader and deeper way, constituting one of the relevant dimensions for explaining the dynamics of development and the underdevelopment of countries and regions.

Considering the current and the historical contexts, the objective of this paper is to analyse the relationship between culture and development, exploring the "developmentalist" approach. Although developmentalism has had a long tradition, we focus on authors who explicitly assumed a structural and unbalanced perspective. In particular, we concentrate on four authors considered crucial to this perspective: Gunnar Myrdal, Raúl Prebisch, Albert Hirschman and Celso Furtado. These authors rejected the neoclassical equilibrium approach and incorporated Keynesian concepts, particularly Keynes' theory of growth.

One of the central arguments of the article is that there is an interrupted agenda, that is, the return of the neoclassical school as the dominant paradigm is economics gradually reduced the ways in which culture and cultural 
factors have been incorporated into economic theory. In other words, we state that there is a gap in the literature on this theme. The orthodox field, after promoting the separation of culture and economics, is trying to analyse the relationship between both concepts but with limited and unrealistic assumptions. Likewise, how the post-Keynesian and institutionalist - among other heterodox - approaches have been incorporating this theme is still limited. Actually, given their broader and more realistic assumptions, the heterodox field has much more potential to effectively incorporate culture into developmental studies. However, we note a lack in some advances that historically had already been considered.

Another key goal of this article is to explore the interpretation of Celso Furtado (1920-2004), recognized as one of the main authors who remarkably advanced the comprehension of the role of culture in the developmental process by incorporating the so-called "cultural dimension of development". According to him, only by considering the relationship between culture and development is possible to understand the origins and historical character of development and underdevelopment.

Analysing the evolution of Furtado's writings, we stress the fact that the importance of culture and creativity has progressed in his analysis, acquiring a major status in the 1970s. In this trajectory, his understanding of these issues also changed, since it is not attached to a restricted and precise concept. Accordingly, Furtado elaborated the notion of system of culture. It is precisely in the elaboration of this system that the notion of culture as a creative process emerges, which is explored in this article. Especially in the book Criatividade e dependência na civilização industrial [Creativity and Dependency in Industrial Civilization] (1978) $)^{1}$, the author is devoted to explaining how and why some economic structures emerged in response to European economic expansion.

In brief, we intend to highlight the originality of the developmentalist tradition and also to defend the need for considering the cultural dimension in the new approaches of the developmental process. Next, inspired by this tradition, we discuss the potentials and limitations of recent approaches in integrating development and culture in an effective way. In particular, we analyse the post-Keynesian perspective which shares hypotheses and methodological similarities with developmentalism and 
institutionalism. Furthermore, we present some suggestions for stimulating this integration and the understanding of development as a cultural process in this perspective.

The article is organized into three main sections. Section 2 discusses how the cultural dimension has been incorporated in economic theory, focusing mainly in recent debate on the developmental process in "mainstream" studies. We argue that this incorporation has been partial and incomplete. The third section shows, in turn, how the cultural dimension of the developmental process is remarkably considered by the developmentalist approach. Celso Furtado's approach is particularly explored, aiming to highlight its relevance and originality, as well as the strong links between culture and development. Finally, in section 4, we discuss some possibilities of incorporating these pluralistic perspectives in the current debate on the developmental process, dealing especially with the post-Keynesian approach and institutionalists. These are close to the structural perspective.

\section{Culture and development in mainstream approaches}

\subsection{Culture in the rise of economic thinking}

Culture and cultural factors have been historically considered in economic theory, although the attention to this issue has fluctuated intensely over time. Initially, as the so-called classical school arose, establishing the discipline of Political Economy as a scientific field of knowledge, the cultural elements used to be encompassed and explored in economic theory. Founding authors such as Adam Smith, Jean Baptiste Say, John Stuart Mill and Robert Malthus, among others, promoted this school of economic thinking in $18^{\text {th }}$ and $19^{\text {th }}$ centuries which constituted a promising field for analysing the relationship between culture and development. The broad "critique of political economy" produced by Karl Marx and his followers also comprises cultural and institutional characters that are crucial for economic analysis. Indeed, for Smith as well for Marx, values and institutions constitute parts of the economic system. These authors did not analyse the specific relationship between culture and economics as they understood these "two concepts to be inherent and mutually complementary" (Petrakis, 2014, p. 31). 
In contrast, the theoretical framework established from 1870 by the neoclassical school was focused on mathematical and abstract formulations of economic relations. Authors such as León Walras, William Jevons and Alfred Marshall proposed and synthesized the main theoretical principles of this approach. This movement implied setting the economy apart from political and social elements, producing a separation of culture and "economics", the new name of the discipline for these authors. Actually, this change of name from political economy to economics implies the intention of creating a pure science, free of political and ethical aspects and then of cultural values (Chang 2014; Petrakis 2014).

In this mainstream approach, culture has been progressively abandoned:

As economic theory increased its mathematical sophistication and the set of tools at its disposal expanded, no need was felt to introduce additional potential explanatory variables, especially those hard to measure. Not only did economics lose interest in its relation with culture, but as economics became more self-confident in its own capabilities, it often sought to explain culture as a mere outcome of economic forces (Guiso et al., 2006, p. 27)

This tendency has been historically criticized. Petrakis (2014) points out that the first opposition, especially to the individual principal of marginal utility, was made by the institutionalists (mainly Veblen and Commons) and sociologists such as Max Weber.

Weber developed an analysis that links the rise of capitalism with beliefs and ethical aspects of Protestantism. To him, the new practices and institutional changes had powerfully favoured the development of a new system of production and economic expansion. The conception of Weber largely influenced social analyses, including those more specifically devoted to the economic field.

Veblen (1899), as well as Commons and Mitchel developed a new school of thought in economic analysis called "institutionalism". They are considered the first generation of institutional economists, also known as "old institutionalists", who highlighted the role of institutions in economic theory (Chang, 2014). For these authors, the emphasis of neoclassical analysis on rational individuals whose behaviour was considered a given fact was very unreal and problematic. Instead, they proposed that individuals were influenced by social conditions and the environment. Individuals are, to a large extent, shaped by institutions and rules, which are historically established, and changed.

We may note that institutionalism reinforced the critics to the neoclas- 
sical approach and opened up possibilities of incorporating culture into economic analysis. If culture was not a part of the economic system, as it was in the classical approach of Smith and Marx, institutionalists at least had firmly recovered the importance of analysing the relationship between culture and development. Institutionalism also largely influenced economic policies such as the New Deal (Chang, 2014). Together with Keynesian theory, institutionalism was also important for the growth of the developmentalist tradition in the mid- $20^{\text {th }}$ century, which we will focus on in section 3 .

\subsection{The return of culture in new mainstream approaches and the displacement of the comprehensive notion of development}

In the orthodox field, cultural and historical elements were separated from "economics". The picture changed in the late $20^{\text {th }}$ century and early $21^{\text {st }}$ century, as many researchers began to recognize that considering culture could enrich the comprehension of economic facts.

Nearly a century after the separation of economics and culture, the neoclassical approach has been trying to bring culture back into economic analysis (Petrakis, 2014). Nevertheless, without abandoning their principles, this approach usually deals with culture as an external input. According to Guiso et al. (2006), the literature usually identifies three "channels of transmission" through the culture that affect economic results.

The first channel of transmission refers to the effects of beliefs on economic decisions. Taking culture into consideration can help in understanding how these beliefs are shaped, and how they influence people's decisions. In this view, several studies developed with the intention of measuring and testing to what extent some cultural variables, such as religious formation and ethnicity, could affect people's decisions. Another topic of recent studies is how cultural heritage affects beliefs and decisions of people in some specific region or country (in the case of high rates of immigrants, for example). In this perspective, special attention is paid to how culture and beliefs shape trust, which largely affects economic decisions. According to Guiso et al. (2006), trust is particularly relevant when transactions require an "unknown counterpart" and when legal protection is imperfect, which has important implications for international trade. 
The second "channel of transmission" regards the effects of preferences and values on economic outcomes. These effects can be divided in two: a) the way that collective or socialized values influence individual values (considered as parameters into a utility function); and b) the way that "political preferences" affect economic results. The third channel states that as culture affects beliefs and values, the effects of culture on political results can be relevant and amplified.

In this debate, we deal with two other challenges. The first is related to the definition of culture, which largely differs across the field of analysis. According to Alesina and Giuliano (2015), a definition that has been increasingly accepted is that culture consists of "customary beliefs and values that social, ethnic and religious groups transmit in an unaltered way through generations" (Guiso et al., 2006). Despite the variability of definitions, Hill (2005) argues that they display some characteristics in common which reflect some conceptions: a) the idea of culture is broad, including knowledge, beliefs, habits and attitudes; b) the forms of culture refers to the behaviour of people and way of living in a specific group, or as a society; c) different groups or societies can have different cultures; and d) culture is passed through generations.

Other challenge regards how culture is measured. According to Alesina and Giuliano (2015) and Castellani (2019), the collection of data about culture is made by using different techniques which can be divided into three categories: a) research in which people interviewed evaluate the importance of a given range of items related to "values"; b) epidemiological studies in which the units of observation are the immigrants in a host country; and c) experiences with game theory and public goods.

Simultaneously, a new understanding of development is in process. The identification of development with productive and structural transformation is being replaced by a range of unarticulated goals which are measured by individual optics (see Chang, 2011a). This "new vision" is increasingly growing in international agencies, influencing their activities and discourse; it is a trend that is compatible with the neoclassical perspective.

Hence, in this debate, we recognize some theoretical and empirical advances of these orthodox economics (especially the neoclassical and the new Keynesian approach). Nevertheless, we argue that the role of culture is much broader and relevant. We also defend the need for comprehensive analysis and interpretation which must go further than the mainstream 
perspective based on quantitative analysis. That is the intent of the next two sections.

\section{Culture in a developmentalist approach}

\subsection{Culture in structural and unbalanced developmentalism}

If culture has hardly been incorporated in recent mainstream approaches to the developmental process, we can state that things are different in the developmentalist approach. Indeed, the relationship between culture and development was fruitfully analysed by authors classified as "developmentalists". Actually, rather than being an established school or approach, developmentalism has been considered a tradition in which authors have historically and periodically addressed questions and theories while this tradition has powerfully influenced economic policy (see Chang, 2014). Although the list of authors of this approach usually includes some pioneers such as Rosenstein-Rodan, Arthur Lewis and Ragnar Nurkse, among others (Petrakis, 2014; Bresser-Pereira, 2019), our focus is on the succeeding authors who explicitly work with a structuralist and unbalanced perspective: Albert Hirschman, Gunnar Myrdal, Raúl Prebisch and Celso Furtado.

This more restricted demarcation of the developmentalist approach allows us to deal with key authors and works in the field as they explored the role of culture and institutions in their investigations of the developmental process in a fertile way. They admitted some principles and ideas of early developmentalism and institutionalism, but they also built new interpretations and theoretical systems. Arguing for the dominant liberalism, this approach has advanced arguments against the free market and defended interventionist positions, especially in favour of less developed countries. In relevant academic works, these authors rejected neoclassical theory and its methodological individualism. Their perspective is based mainly on the Keynesian theory of growth, with a more collective or class approach. They also advocate incorporating political aspects into economic analysis.

The developmentalist approach became progressively dominant from the 1940s to the 1960s, strongly influencing economic agendas and public policies all over the world in the post-Second World War years. From 
the 1970s, and actually in the 1980s, this approach faced a crisis, and the neoclassical view tended to be dominant again (Hirschman, 1981; BresserPereira, 2019). For the purposes of this article, we stress three key characteristics of this thought as crucial to its analysis of the relationship between culture and development.

First, it established a new perspective of the process of development related to the equilibrium. Authors firmly rejected stability tendencies and automatic self-correcting forces, advocating that different movements occur in the developmental process. Of particular interest is the concept of development as an unbalanced process, which is elaborated by Hirschman. The author criticised the perspective of balanced development, particularly the approaches of Rosenstein-Rodan, Nurkse, Lewis and Scitovsky. He neglected the idea of two stability states, one for development and the other for underdevelopment, questioning the argument that a move from underdevelopment to a development equilibrium must happen with simultaneous elements (Hirschman 1961, p. 85). In contrast, in Hirschman's perspective, development is an unbalanced process in which the transformation happens through a series of impulses and reactions that move the several elements of the economic system in the chain. In this approach, the focus is on the linkages that occur between the elements of the system, such as industries and sectors, that can be applied in other fields (Hirschman, 1977). A similar conception can be founded in Myrdal (1984), who explores the unbalanced role of the accumulation process. In his view, the social process does not progress towards an equilibrium. Instead, any new factor tends to provoke several reactions in the chain, reinforcing or amplifying the initial impulse across the social process. The formulation of the well-known "principle of cumulative causation" plays a central role in his conception, reinforcing the argument that the free market does not enhance the tendency towards equilibrium and equality. On the contrary, without intervention, initial economic and social inequalities tend to become amplified with time (Myrdal, 1957, 1984; Furtado, 1980).

Second, the developmentalist approach adopted a structural analysis and rejected positivism and methodological individualism. Myrdal (1984) powerfully questioned the use of the principle of the rational individual as the organizer of a harmonic society. In this perspective, he critically examined the differences between family budgets and macroeconomic 
dynamics. Furtado (1980, p. 42) states that "the starting point of reflection on development is the apprehension of social reality... This reality is apprehended (...) as something structured and that occurs unfolding in time. The idea of structure is the starting point for the apprehension of a whole or totality, whose form can be described by rules that translate relationships between parts of this whole".

The structuralist approach challenges the methods based on empiricism and positivism. The basic guiding principle is the conception of an integrated system of elements that is diverse but also mutually constituted, highlighting the systemic character of development (Missio et al., 2015). This conception moves the analysis away from methodological individualism and gets closer to a methodological holism in which the whole is more than the sum of the parts, or the totality is hierarchically superior to the individual.

Moreover, Latin American structuralism has considered the specific economic and, to a certain extent, cultural characters of the region and has produced some of the most important theoretical elaborations in the field of developmental theory. The theoretical basis of Latin American structuralism was established by Prebisch (2011a), who first published in 1949. In this approach, later called the centre-periphery approach, the theory of deteriorating terms of trade has played an important role, causing a fissure in the well-stablished field of followers of the comparative advantage theory. Other succeeding essays added more questions and explanations for the economic problems of underdeveloped countries (Prebisch, 2011a, 2011b) with regard to inadequate international insertion and specialization, as well as the insufficiency of the productive system and institutional features. These contributions led to the rise of a new theoretical approach to the developmental process and problems of underdevelopment, with a focus on international economic relations and the institutional framework. Moreover, these theoretical advances were settled in Latin America, in the Global South. Another important author who contributed to establishing this approach was Anibal Pinto, who developed the concept of structural heterogeneity, focusing on the great differences in productivity among industries, social groups and regions within Latin American countries (Pinto, 2000).

Furtado has decisively contributed to the consolidation of Latin American structuralism as he brought a historical perspective into the centre of 
economic analysis. This is a well-known characteristic of his books regarding the economic formations of Brazil and Latin America (Furtado, 2000; 2007). His classical book Economic Formation of Brazil (2000), called a "masterpiece of ECLALC structuralism" (Bielshowski, 1989), analyses the economic cycles of Brazilian history using a structuralist framework. Furtado (2007) explores the different forms of industrialization across countries in Latin America, according to the characteristics of the exporting economy and the main products of exportation. The question of income distribution and its relationship to growth and development was also largely and sophisticatedly explored by this author in many works. By doing this, Celso Furtado and Aníbal Pinto explored a dimension of inequality and incorporated it into economic analysis (Pinto, 2000; Bielshowski, 1989, 2011; Silva et al., 2016).

Furtado (1973, p. 72) highlights economic structuralism as a school of thought that originated in Latin America in the 1950s whose main objective was to reveal the importance of "non-economic parameters of the economic models". The behaviour of economic variables largely depends on these parameters, and the nature of these parameters can be significantly modified in times of rapid social change or when the period of analysis is amplified. This means that non-economic parameters must be strongly considered in economic analysis, especially in heterogeneous economic systems in less developed countries.

Third, the developmentalist approach also advances a broader understanding of development, which is seen as a comprehensive process with multiple dimensions. Economic transformation is analysed together with historical, political and institutional aspects. Myrdal states that social life, instead of being a logical system, results from historical development in which institutional elements play an important role. He highlights the interaction between political and economic factors and strongly defends the need for incorporating political elements, economic interests and power relations into economic analysis and theory (Myrdal, 1984).

Hirschman (1981) criticised the dominance of what he called "monoeconomics", which is the tendency to apply neoclassical models of economics to the analysis of countries all over the world. He emphasized that Keynes had demonstrated that this model can only work in the case of full employment, a particular case of economic situation. Thus, the neoclassical model cannot be applied in underdeveloped countries. 
Indeed, Keynesian theory itself can be understood as a defence of planning and coordination, as well as bringing political questions into economic analysis. In later work by Hirschman (1994), explores the connections between economic and political progress in an effective and innovative way.

Thus, the developmentalist approach has created a new perspective for analysing the relationship between culture and development.

\subsection{Culture and creativity in Celso Furtado}

Among the authors examined in our delimitation of the developmentalist approach, Celso Furtado is the most advanced in dealing with development and culture because he explored the so-called "cultural dimension of development process". In his perspective, the cultural dimension corresponds to a process of social changes in which an increasing number of human needs and requests is satisfied by the differentiation in production systems linked to technological innovation. These human needs can be pre-existent or created by the process of change itself.

Actually, we note the absence of a single concept or even a demarcated and enclosed definition of culture in Furtado's thought. This absence is linked to the fact that his thoughts may be grouped into distinct phases. According to Cunha and Britto (2018), these phases have distinct logics of argumentation and are to some degree self-centred. At the same time, these phases are not independent of each other. For example, in the essays Dialética do desenvolvimento [Dialectic of Development] (1964) and Mito do desenvolvimento economico [The Myth of Economic Development] (1974), the role of culture appears, but not with the centrality it acquires in later works.

This perspective largely differs from the specific and delimited definition adopted in mainstream approaches which define culture as a "package" of beliefs and values. We state that the broad and complex character of Furtado's thought requires going further than enclosed definitions which might confine the original and innovative character of his thought. This character is related to an idea of comprehensive analysis which encompasses non-economic factors. Thus, we defend Furtado's view that culture is related to explaining how and why different pro- 
cesses occur in an organic system. This means that the author is more devoted to formulating and analysing a "system of culture" in which the whole may be understood by the interactions of its constituting elements (Furtado, 1964).

Furtado (1964) uses the "philosophical anthropology Hegelian" (Bolaño, 2013). At same time, this book connects an anthropological approach to the process of social change with a conception of historical development which is appropriated from Marx in order to formulate a system of culture (Borja, 2013).

This approach usually distinguishes three basic spheres: a) the material culture, which refers to economic aspects and is expressed in technical progress and capital accumulation; b) the non-material culture, meaning the socio-political domain, shaped by ideas and values, as well as political actions linked to these ideas and values; and c) the elements of non-material culture not included in the socio-political sphere, such as philosophical reflection, mystical meditation, artistic creation and scientific research (Borja, 2013; Cunha and Britto, 2018).

In this formulation, Furtado emphasises both material and non-material elements:

The development of material structure basis requires adaptation of non-material superstructure (...) As culture is a whole of independent elements, every time that, under some specific historic conditions, the technology advances and the material basis develops, all other elements are required to adjust to the new conditions... these adjustments originates a series of new process with effects on material basis (Furtado, 1964, p. 19, translated by the authors)

In other works, Furtado outlines different concepts of culture, each one covering distinct dimensions of his thought which are adequate for the discussion. In the 1970s, the essays Criatividade e dependência na civilização industrial [Creativity and Dependency in Industrial Civilization] (1978) and Cultura e Desenvolvimento em época de crise [Culture and Development in Times of Crisis] (1984) denote the major centrality of the cultural dimension (Borja, 2013). In this phase, culture has the role of generating a creative process which can rupture the old structures of development. Thus, Furtado definitively connects culture with the idea of creativity in analysing the particular dynamics of the developmental process (Cunha and Britto, 2018).

Finally, we stress that in Furtado's view, the connexion between culture and creativity is very relevant and complex, preventing unidirectional and 
simplistic understandings regarding this connection (Cunha and Britto, 2018 , p. 179). Indeed, Furtado is not limited to the understanding of culture as one "dimension" of social reality as he sees culture as an "entire reality" (D'Aguiar, 2012, p. 18, translated by the authors). In this reality, cultural activity relies on "creativity, which is linked with the rupture with establishment" (Furtado, 2012, p. 65). This means that creativity is rooted in the past and at same time is associated with rupture. Moreover, we can state that it is an open an undetermined movement that is constantly changing, even in the context of a socially structured space.

According to Furtado, "if we know little about the laws of cultural creativity, there is abundant evidence that the field of possibilities in this creativity is wider than we think under the influence of religious and philosophical tradition" (Furtado, 2008, translated by the authors). At the same time that the field of creativity is ample, the culture of a specific society may be subjected to a particular purpose which may limit the creativity. This was the case of culture that emerged during the bourgeois revolution which subordinated the forms of creative activity to the process of transformation in the physical world that was required by the accumulation process.

Furtado (2008) explores the constitution of industrial capitalism and economic globalization, highlighting the role of initiative and creativity. In his view, the formation of industrial capitalism has two axes: a) the great and growing transnational firms/companies, which leads to the transformation of atomized markets into oligopolistic structures; and b) the rise of national states, which slowly incorporates broader parts of the population into political participation and consumer markets. These axes imply a concentration of power that characterizes industrial capitalism, which must be seen not only as a productive organizational form but also as a "system of social organization".

The initiative and capacity to influence markets emerge, which were not present in atomized and adaptive small firms. The amplification and complexification of international economic relations need coordination and decision centres. This coordination was firstly made by the consolidating national states, but it has progressively moved from national states to the big transnational companies. The "capacity of initiative is a key strategic factor in this system in continuing transformation: (...) these companies make the maximum of initiatives in the field of accumulation and 
orientation of creativity" (Furtado, 2008, p. 45, translated by the authors). In economic analysis, a huge change took place with the emergence of macroeconomic theoretical tools, as the productivity concept moved from the individual to social scopes.

The establishment of the industrial capitalism is analysed in a structural and historical perspective as an outcome of several periods of change in the accumulation process. The unprecedented commercial expansion, associated with productivity growth and diffusion of cultural values, created the basis for the "industrial civilization". The industrial civilization is shaped by two converging processes of cultural creativity: the bourgeois revolution and the scientific revolution (Furtado, 2008).

In occidental Europe, the site of the rise of industrial civilization, two systems of culture coexisted in the mid- $15^{\text {th }}$ century. The old system, based on religious tradition and on the control of access to land, showed a tendency towards immobilization and permanence. But the growing importance of urban life, where the bourgeois revolution was being elaborated, brought new elements to this picture. The Reform movement, despite some contradictions, meant a kind of rupture in the religious realm. This rupture opened the possibility of introducing new values and ideas and was rapidly used to produce a large cultural revolution (Furtado, 2008).

This broader notion of industrial civilization, including culture in the developmental process, is a key concept in Furtado's analysis. The development of industrial civilizations was a process that took place in a few countries, mainly in central Europe. Even in this small group of countries, the process was highly uneven. The diffusion of this process across the world reached a great variety of forms and intensity. In this context, the idea of "progress" worked as a goal for the new societies. On the other hand, the notion of "development" was marked by some ambiguities (Furtado, 2008).

In this perspective, development is a process of social change associated with creativity: instead of reproducing the same things or structures, it includes new things and facilities, expanding the space of possibilities and achieving human potential. This meant a challenge to inventiveness. Actually, Furtado states that the "wonderful range of cultures" that emerged in world history expressed the "fabulous potential of human inventiveness". 
The process of cultural creativity is marked by two characteristics: first, this process is not related or limited by the level of accumulation. At levels of accumulation considered nowadays very low, some civilizations have arisen and, in many respects, have not been overcome yet. Second, this process, instead of being regular and continuous, tends to be discontinuous and spasmodic, having intense and concentrated impulses in the beginning and rapidly slowing down. Although irregular, this process is not erratic: its essential basis evolves within a "structured space": "Initially, the society reproduces itself and then establishes a diachronic relation with culture. In this picture, the "dialectic of innovation" is limited and only can emerge by the discontinuity" (Furtado 2008, p. 112, translated by the authors).

Attempting a global view, Furtado points out that industrial civilization is produced by the convergence of two processes of cultural creativity: the bourgeois revolution and the scientific revolution (Furtado, 2008). The space of culture is delimited by the creative actions of human beings who express their liberty (Furtado, 2008). Thus, cultural elements have played an important role in the emergence of industrial civilizations. They are also present in the possibilities of questioning and overcoming this civilization. Furtado highlighted three critical aspects: a) the transformation of artistic creation: from objects that can be captured by the accumulation system, the creativity moves to the artist, who invents a new language, eliminating the boundaries between artistic's and life's creation; b) the ecological movement, questioning the private use and exploration of nonrenewable resources; and c) the feminist political claims requiring equality in productive and family reproductive life (Furtado, 2008). After this book, the intellectual production of Furtado definitely incorporates culture as a central aspect of his theoretical formulation of the developmental process. Indeed, in later works of Furtado $(1984,1999)$, culture increasingly occupies a central position in his analysis.

Therefore, the developmentalist approach established a broad theoretical organisation for the analysis of the relationship between culture and development. The three key points that we highlighted are crucial to understanding the contribution of this approach. We argue that this broad approach goes further than methodological individualism and is much more appropriate for analysing culture and development, as Furtado has demonstrated, leading to the major advances on this issue. 


\section{Contributions of the developmentalist approach to a pluralistic perspective in the current debate on de- velopment: questioning the post-Keynesian viewpoint}

Founded on the developmentalist approach, we argue for moving away from the mainstream economic understanding of culture as a static "package" of beliefs and values and for dealing with approaches that elaborated a broader notion of culture which can effectively be related to economic and developmental analysis. Jackson (1993, p. 462) points out that three non-neoclassical economic schools of thought are able to deal with culture in an interesting way: Marxian, institutional economics and post-Keynesian.

Considering that the developmentalist approach offers a more adequate view for analysing the relationship between culture and development, we now examine a recent theoretical perspective that also uses a structuralist methodology and moves away from methodological individualism: the post-Keynesian approach. We consider this approach appropriate as it takes a structural view of economic problems and tries to identify specific factors for each structure. Understanding that there are some interactions between this approach and structuralism, we discuss some points of the post-Keynesian approach in analysing the relationship between culture and development, exploring some limitations and potentials of this approach.

Following Furtado (2000), we agree that it is necessary to emphasize "non-economic parameters" in macroeconomic models. Therefore, "since the behaviour of economic variables depends on those parameters, which 'take form and evolve in a historical context', it is not possible to separate the study of economic phenomena from their historical context (Boianovsky, 2009, p. 853).

In addition, we emphasize that this analysis could be extended to other approaches that have some similarities to post-Keynesianism, such as the institutionalist approach (Hodgson, 1999; Wray, 2007) and Regulation Theory (Setterfield, 2011), and are likely to incorporate cultural elements into their theoretical body (Jackson, 1993).

In the context of a monetary production economy, there is a fruitful field for economic studies that emerges from mediations between these different approaches: analysing the dynamics of financially modern capital- 
ist economies by considering the uncertainty of this context. Although this discussion is beyond the scope of this work, we can outline some points.

For instance, Arestis (1996) states that this institutionalist tradition "strengthens two weak elements in post-Keynesian analysis" associated with the determinants of expectations and with microeconomic analysis. Next, the author discusses and proposes improvements to the postKeynesian approach by exploring this tradition. In fact, institutionalist analysis amplified and spread its influence among academic researchers as well as policy makers from the 1990s, especially in the debate on development. But instead of the evolution of post-Keynesian analysis in this direction, we have seen the predominance of the free-market view in the so-called "better institutions" and "good governance". These notions have been used to influence the adoption of typically Anglo-American institutions by developing countries, many times by using "governance related conditionalities" in international loans (Chang, 2011b). We understand that this type of analysis is far from the developmentalist approach.

On the other hand, we recognize that there are important interactions between post-Keynesian theory and the structuralism which is present in diverse approaches. These interactions arise, above all, from methodological similarities. Post-Keynesian theory admits that capitalist economies are composed of social structures that exist without being scientifically observed, that is, capitalism is based on "realism". More specifically, there are important social structures that largely determine the behaviour of economic agents, social institutions and social organizations. These structures form the nature of the money-producing capitalist economy. While post-Keynesians believe that capitalist economies exhibit certain regularities generated by causal mechanisms that can be captured by economic theories, they conceive the economy as a dynamic system subject to a permanent change in historical time.

Additionally, post-Keynesians reject the idea that social structures or macroeconomic phenomena can be reduced to the behaviour of individuals. From this perspective, reasonable behaviour at the micro-level may not generate the intended results at the macro level when interrelationships between individual actions are taken into account (Hein, 2016). Individuals always act in a certain institutional context that shapes their beliefs and actions and connects different classes of agents or types of economic units to each other. In this context, social structures and macroeconom- 
ic phenomena can exercise causal powers that affect human behaviour which, in turn, determines macro-phenomena (Lavoie, 2014).

Although the post-Keynesian approach has put emphasis on macroeconomic elements, namely production and growth, we state that this approach recognizes the role of culture in economic dynamics. As pointed out by Arestis (1996), post-Keynesian economic theory relies on three traditions. The first stresses uncertainty and is associated with an endogenous theory of expectations and with the non-neutral character of money. The second emphasises the role of effective demand and sees investment demand as the driving force. This tradition makes a "distinction between social classes rather than the neoclassical classless and atomistic base". The third tradition is rooted in Veblen institutionalism, which is "process and evolution oriented" and emphasises the "dynamic and power/class structure of economic systems". In these three points, we can see the potential to incorporate culture into the analysis.

We discuss two points of the post-Keynesian approach that we found as having the potential to bring cultural aspects into economic analysis. The first point we highlight in the post-Keynesian approach regards the active role of culture as it relates to the importance of expectations, a key element in Keynesian theory. Indeed, culture is important for explaining expectations because expectations result from trust and the weights that people give to outcomes and alternatives.

On this point, following the Keynesian tradition, uncertainty is a central concept with regard to the dynamic of capitalist economies. In an uncertain environment, people make decisions based on trust in expectations and on the degree of uncertainty that they are able to face, since they know that the confirmation (or lack of confirmation) of expectations will happen in the future. This means that since the future is uncertain, investors, for example, follow their "animal spirits", largely based on convention. Consequently, expectations are a question of probability, weighted by "degree of beliefs". The beliefs have little to do with the kind of stochastic calculations done by agents with rational expectations. Instead, beliefs and preferences are shaped by culture, which means that culture plays an important role in economic dynamics (Dequech, 2000).

Fernández-Huerga (2008) elaborated a behavioural model appropriate for an institutional and post-Keynesian approach. In this model, human behaviour is divided into motivation, cognition and reasoning, and deci- 
sion-making. The first appears as a process directed toward the satisfaction of a complex structure of various needs and wants. Next, it recognizes the role of emotions and the social and cognitive aspects of motivation. Human beings have limited cognitive and rational capacities at the same time as they are potentially creative. Therefore, cognition becomes at least partially a social act and knowledge of reality is subject to fundamental uncertainty. In that context, the humans in the decision-making process use their mental abilities to process information and choose the course of action with which they hope to achieve the objective determining their motivation. However, humans have cognitive limitations and restricted abilities for reasoning and processing all the information available. In short, "human rationality (or intelligence) is associated with a search for good solutions, and it includes elements of procedural rationality, creativity, and emotional rationality" (Fernández-Huerga, 2008, p. 709).

The second point we highlight is related to the conception and behaviour of the firm. The experience, expectations and practical rules for establishing the price mark-ups are formulated according to institutional structure, which is highly related to culture. Indeed, firms tend to follow procedures and rules historically established that are related to their own culture and to the culture of their environment. Even the process of learning is largely conditioned by culture as it requires interaction and thus sharing of language, information and codes.

In that same sense, it is also possible to recognize that each organization has its own ideology formed by a set of beliefs and claims. This ideology is part of the firm's culture. In this context, it is possible to "match different types of information selectivity with particular organizational forms and in sketching how the types of information selectivity structure perceptions of uncertainty" (Heap, 1986, p. 277). The perception of uncertainty is connected to society's institutions or, more generally, its power distribution. Hence, uncertainty is no longer considered as some independent source of social explanation (Heap, 1986).

Finally, we discuss the possibility of incorporating certain aspects related to culture to explain, for instance, the determinants of income elasticity of demand for imports (and thus the external restriction on growth) in the post-Keynesian growth models. More specifically, one of the fundamental questions in the Balance of Payment Constrained Growth (BoPG) models is to understand the determinants of income elasticities of 
demand associated with foreign trade. Discrepancies in these elasticities between countries result in different degrees of restrictions on economic growth. We argue that culture in its multiple dimensions could help to explain these differences.

For example, empirical literature has shown that the magnitude of the income elasticity of demand for imports, which is substantially higher in underdeveloped countries, causes a more active external constraint. We understand that the occurrence of the "demonstration effect" of conspicuous consumption (Nurkse, 1957; Furtado, 1961, among others), connected with interpretations of the concept of habits and institutions and the Veblenian idea of emulation (Veblen, 1899), may constitute an interesting way of explaining the difference evidenced by the empirical literature. Conspicuous consumption by the wealthiest classes sets consumption patterns (and, consequently, production patterns) that reinforce the structural characteristics of the periphery and contribute to deepening the stratification of the social structure.

Thanks to the huge force of means of advertisement and communication, the habits of consumption go in advance, as the cart ahead of the oxen. Because of this, there are motives to believe that the spontaneous development of current underdeveloped countries occurs at a lower rhythm than one could expect, given the potential of these economies and the technical progress already achieved (Furtado, 2010, p. 346, translated by the authors).

Another possibility is that, within Kaleckian growth models, there are very few analyses that take into account cultural aspects, when in fact they are important for explaining variables such as aggregate savings, income distribution and investment, even in a restricted approach and from the perspective of short/medium-term macroeconomic models.

Thus, these are examples of how, within post-Keynesian theory, it is possible to advance our understanding of the role culture plays in economic development, using interesting standpoints.

\section{Final Remarks}

The relationship between culture and development has a long history in economic analysis. Historically, culture and cultural factors have been incorporated by economic analysis in an uneven trajectory. From the rise of political economy to the emergence of neoclassical economics, there 
is a progressive separation between cultural and economic dimensions. The succeeding critics and theoretical framework undertaken by institutionalism and by the Keynesian approach promoted the return of culture into economic analysis in the heterodox field while its absence marked the mainstream approach over a long period of time.

In the last four decades, however, the mainstream approach has been trying to deal with cultural factors and the background of economic studies. In this article, we briefly examined this literature and show that this attempt has been quite limited and incomplete, basically for three reasons: 1) they assume a static and narrow concept of culture, founded on traditional elements; 2) they keep methodological individualism and unrealistic assumptions in analysing non-economic elements; and 3) they tend to be timeless and a-historical. Furthermore, and related to this insufficiency, we note that there's a current tendency to replace the notion of development, historically linked to structural changes, with a diffused perception of improvement in indicators at the individual level.

However, in the heterodox field, diverse approaches have been advanced. Influenced by the critics to the neoclassical approach and the consolidation of a new theoretical framework by institutionalists and Keynesians, the developmentalist approach remarkably contributed to amplifying the integration of culture and development. These authors have largely influenced economic analysis and policy during the $20^{\text {th }}$ century.

This article has explored the richness of the developmentalist approach on this issue. This approach embraces a broader conception of culture, considering diverse aspects of human life and how they influence the dynamics of development and underdevelopment. Founded on structuralist methods, the developmentalist authors has conducted comprehensive analysis, considering multiple and interacting aspects. By doing this, the developmentalist approach has established an agenda of research and policy that has been interrupted and that we call "lost", echoing the nice title of Proust's book.

We evaluate how, and to what extent, this approach can contribute to the current debate. In this attempt, we analyse current approaches, such as the institutionalist and mainly post-Keynesian approaches, examining how they are dealing with the cultural dimension of development. We conclude that these approaches show an interesting potential for incorporating the cultural dimension of development but are still focused on eco- 
nomic factors and on the short-run. In the end, and somewhat inspired by the developmentalist's "lost" agenda, we briefly discussed and suggested some possibilities for this integration.

In terms of future studies, we indicate the need to incorporate historical and regional specificities in the analyses of culture and development. An integrated analysis of the global culture system and the factors specific to each country/region as well as the specific developments that arise from this interaction are needed. Again, Celso Furtado's thought is a source of inspiration since, in the analysis of the Brazilian case, for example, the author did not limit himself to presenting a generic discussion, since he related this debate to concrete aspects of Brazilian society. For the author, the richest and most potent Brazilian culture is what stems from its popular roots, and it is from the valorization of popular culture that the country will be able to build an effective process of social and economic emancipation.

Finally, whereas the neoliberal agenda may also be understood as lost since the Great Recession of 2008, we hope that the call for the integration of culture into economic analysis can be answered and that new attempts in this direction may be undertaken in the heterodox field.

\section{References}

ALESINA, A.; GIULIANO, P. Culture and institutions? Journal of Economic Literature, v. 53, n. 4, p. 898-944, 2015.

ARESTIS, P. Post-Keynesian economics: towards coherence. Cambridge Journal of Economies, v. 20, p. 111-135, 1996.

BIELSHOWSKI, R. Formação econômica do Brasil: uma obra-prima do estruturalismo cepalino. Brazilian Journal of Political Economy, v. 1, n. 4, p. 38-55, 1989.

BIELSHOWSKI, R. Prebisch e Furtado. In: GURRIERI, A. (Org.). O Manifesto Latino-Americano e outros ensaios. Rio de Janeiro, RJ: Contraponto, Centro Internacional Celso Furtado, p. 7-14, 2011.

BOIANOVSKY, M. Furtado, North and the New Economic History. EconomiA, Brasília (DF), v. 10, n. 4, p. 849-866, 2009.

BOIANOVSKY, M. A view from the tropics: Celso Furtado and the Theory of Economic Development in the 1950s. History of Political Economy, v. 42, n. 2, p. 221-266, 2010.

BOLAÑO, C. Considerações sobre o conceito de cultura em Celso Furtado. In: D’AGUIAR, R.F. (Org). Celso Furtado e a dimensão cultural do desenvolvimento. Rio de Janeiro: E-papers: Centro Internacional Celso Furtado, p. 87-123, 2013.

BORJA, B. Notas sobre a dimensão Cultural em Celso Furtado. In: D’AGUIAR, R.F. (Org). 
Celso Furtado e a dimensão cultural do desenvolvimento. Rio de Janeiro: E-papers: Centro Internacional Celso Furtado, p. 125-153, 2013.

BRESSER-PEREIRA, L. C. From classical developmentalism and post-Keynesian macroeconomics to new developmentalism. Brazilian Journal of Political Economy, v. 34, p. 247-266, 2019.

CASTELLANI, M. Does culture matter for the economic performance of countries? An overview of the literature. Journal of Policy Modeling, v. 41, n. 4, p. 700-717, 2019.

CHANG, H. J. Hamlet without the Prince of Denmark: how development has disappeared from today's "development" discourse. In: KHAN, S. CHRISTIANSEN, J., (eds.) Towards New Developmentalism: Market as Means Rather Than Master, pp. 47-58. Abingdon: Routledge. 2011a.

CHANG, H. J. Institutions and economic development: theory, policy and history. Journal of Institutional Economics, v. 7, n. 4, p. 473-498, 2011 b.

CHANG, H. J. Economics: the user's guide. London: Penguin, 2014.

CUNHA, A. M.; BRITTO, G. When development meets culture: The contribution of Celso Furtado in the 1970s. Cambridge Journal of Economics, v. 42, n. 1, p. 177-198, 2018.

D'AGUIAR, R. F. Introdução: Pensando a Cultura. Organização: Rosa Freire d'Aguiar Furtado. Rio de Janeiro: Contraponto: Centro Internacional Celso Furtado de Políticas para o Desenvolvimento, 2012.

DEQUECH, D. Fundamental uncertainty and ambiguity. Eastern Economic Journal, v. 26, n. 1, p. 41-60, 2000.

FERNÁNDEZ-HUERGA, E. The economic behavior of human beings: The institutional/postKeynesian model. Journal of Economic Issues, v. 42, n. 3, p. 709-726, 2008.

FURTADO, C. Desenvolvimento e subdesenvolvimento. Rio de Janeiro: Fundo de Cultura, 1961.

FURTADO, C. Dialética do desenvolvimento. Rio de Janeiro: Fundo de Cultura, 1964.

FURTADO, C. Formação econômica do Brasil. São Paulo: Cia. Editora Nacional, 1973.

FURTADO, C. Pequena introdução ao desenvolvimento: Enfoque interdisciplinar. São Paulo: Companhia Editora Nacional, 1980.

FURTADO, C. Accumulation and Development:The Logic of Industrial Civilization (S. Macedo, Trans.), NewYork, St. Martin's Press, 1983.

FURTADO, C. Cultura e desenvolvimento em época de crise. São Paulo: Paz e Terra, 1984.

FURTADO, C. O longo amanhecer: Reflexões sobre a formação do Brasil. São Paulo: Paz e Terra, 1999.

FURTADO, C. Teoria e política do desenvolvimento econômico. São Paulo: Paz e Terra (10 ${ }^{\text {th }}$ ed.), 2000.

FURTADO, C. A economia Latino-Americana: formação histórica e problemas contemporâneos. São Paulo: Companhia das Letras, 2007.

FURTADO, C. Criatividade e Dependência na civilização industrial. São Paulo: Companhia das Letras, 2008.

FURTADO, C. Formação econômica do Brasil. São Paulo: Companhia das Letras, 2009. 
FURTADO, C. Formação de capital e desenvolvimento econômico. In: AGARWALA, A. N. and SINGH, S. P. (Orgs.). A economia do subdesenvolvimento. Rio de Janeiro: Contraponto e Centro Celso Furtado, p. 329-354, 2010.

FURTADO, C. Ensaios sobre cultura e o Ministério da Cultura. Organização: Rosa Freire d'Aguiar Furtado. Rio de Janeiro: Contraponto: Centro Internacional Celso Furtado de Políticas para o Desenvolvimento, 2012.

GUISO, L.; SAPIENZA, P.; ZINGALES, L. Does culture affect economic outcomes? Journal of Economic Perspectives, v. 20, n. 2, p. 23-48, 2006.

HEAP, S. P. H. Risk and culture: a missing link in the post Keynesian tradition. Journal of Post Keynesian Economics, v. 9, n. 2, p. 267-278, 1986.

HEIN, E. Post-Keynesian macroeconomics since the mid-1990s - main developments. IPE Working Paper No. 75/2016.

HILL, C. International business: Competing in the global marketplace (5 $5^{\text {th }}$ ed.). New York, NY: McGraw-Hill, 2005.

HIRSCHMAN, A. Estratégia do desenvolvimento econômico. Rio de Janeiro: Fundo de Cultura, 1961. 322 p.

HIRSCHMAN, A. A generalized linkage approach to development, with special reference to Staples. In: MANNING, NASH (Ed.). Essays on economic development and cultural changes in honor of Bert F. Hoselitz. Chicago: University of Chicago Press, 1977.

HIRSCHMAN, A. The rise and decline of development economics. In: HIRSCHMAN, A. O. Essays in trespassing: Economics to politics and beyond. Cambridge: Cambridge University Press, p. 1-24, 1981.

HIRSCHMAN, A. The On-and-Off Connection Between Political and Economic Progress. The American Economic Review, n. 84, v.2, p. 343-348,1994.

HODGSON, G. Post-Keynesianism and institutionalism: another look at the link. In: SETTERFIELD, M. (ed.) Growth, employment and inflation. London: Palgrave Macmillan, 1999.

HODGSON, G. What are Institutions? Journal of Economic Issues, v. XL, n. 1, p. 1-25, 2006.

JACKSON, W. Culture, society and economic theory. Review of Political Economy, v. 5, n. 4, p. $453-469,1993$

LANDES, D. S. A riqueza e a pobreza das nações. Rio de Janeiro: Editora Campus, 1998.

MISSIO, F. J.; JAYME JR., F. G.; OREIRO, J. L. The structuralist tradition in economics: methodological and macroeconomics aspects. Brazilian Journal of Political Economy, v. 34, p. $247-266,2015$.

MYRDAL, G. Economic theory and under-developed regions. London: Gerald Duckworth \& Co. LTD, 1957.

MYRDAL, G. The political element in the development of economic theory. London: Routledge, 1954.

MYRDAL, G. Aspectos políticos da teoria econômica. Sao Paulo: Editora Nova Cultural, 1984.

NURKSE, R. Problemas da formação de capital em países subdesenvolvidos. Rio de Janeiro: Editora Civilização Brasileira, 1957. 
PETRAKIS, P. E. Culture, growth and economic policy. Berlin, Heidelberg: Springer, 2014.

PINTO, A. Natureza e implicações da "heterogeneidade estrutural" da América Latina. In: BIELSCHOWSKY, R. (Org.). Cinquenta anos de pensamento da Cepal. Rio de Janeiro: Record, 2000.

PREBISCH, R. Crescimento, desequilíbrio e disparidades: interpretação do processo de desenvolvimento econômico. In: GURRIERI, A. (Org.). O Manifesto Latino-Americano e outros ensaios. Rio de Janeiro: Contraponto, Centro Internacional Celso Furtado, p. 153-246, 2011a.

PREBISCH, R. Problemas teóricos e práticos do crescimento econômico. In: GURRIERI, A. (Org.). O Manifesto Latino-Americano e outros ensaios. Rio de Janeiro: Contraponto, Centro Internacional Celso Furtado, p. 247-298, 2011 b.

RODRÍGUEZ, O. O estruturalismo Latino-Americano. Rio de Janeiro: Civilização Brasileira, 2009.

SETTERFIELD, M. Anticipations of the crisis: On the Similarities between post-Keynesian economics and regulation theory. Revue de la Régulation [En ligne], 2011. DOI: 10.4000/ regulation.9366

SILVA, G; MARTINS, H.; NEDER, H. Investimentos em infraestrutura de transportes e desigualdades regionais no Brasil: Uma análise dos impactos do Programa de Aceleração do Crescimento (PAC). Brazilian Journal of Political Economy, v. 4, n. 36, p. 840-863, 2016.

VEBLEN, T. The theory of the leisure class. New York, NY: Cosimo Classics, 1899.

WRAY, L. R. Veblen's Theory of Business Enterprise and Keynes's Monetary Theory of Production. Journal of Economic Issues, v. 41, n. 2, p. 617-624, 2007.

\footnotetext{
About the authors

Fabricio J. Missio-fjmissio@cedeplar.ufmg.br

Universidade Federal de Minas Gerais, Centro de Desenvolvimento e Planejamento Regional, Belo Horizonte, MG, Brasil. ORCID: https://orcid.org/0000-0003-4561-6039.

HumbertoMartins_hmartins@ufu.br

Universidade Federal de Uberlândia, Instituto de Economia e Relações Internacionais, Uberlândia, MG, Brasil. ORCID: https://orcid.org/0000-0003-4672-1594.

The authors thank the participants of II Workshop Critical Approaches to Development, especially Robbie Shilliam and Kalpana Wilson for their interesting comments. The authors also thank Niemeyer Almeida Filho, José Rubens Garlipp, Vanessa Petrelli Corrêa and Haroldo Ramanzini Júnior for their comments and suggestions on a preliminary version of this article. Finally, thanks are extended to an anonymous referee for the helpful comments.
}

\section{About the article}

Submission received on December 01, 2019. Approved for publication on February 17, 2020. 